\title{
Sustainability and typology of dairy production systems
}

\section{Sustentabilidade e tipologia de sistemas produtivos leiteiros}

\author{
Kellen Cristina Kuwahara ${ }^{1 *}$; Julio Cesar Damasceno ${ }^{2}$; Ferenc Istvan Bánkuti2 ${ }^{*}$; \\ Rodrigo César Prizon ${ }^{3}$; Diogo Francisco Rossoni" ${ }^{4}$ Ilton Isandro Eckstein ${ }^{5}$
}

\begin{abstract}
The objective of this study is to analyze the typology of dairy production systems (DPS) in Paraná, Brazil, based on sustainable practices adopted by agricultural producers. A total of 153 semi-structured questionnaires containing variables for general characterization of DPS, socioeconomic characteristics of farmers, as well as environmental, social, and economic sustainability actions implemented by rural workers were applied. Common factor analysis (CFA) was used to evaluate sustainability variables. Three factors were created: economic (F1), social (F2), and environmental (F3). Hierarchical clusters were formed using the factor scores obtained in CFA. Three clusters were defined and were compared with F1, F2, and F3. There were significant differences in F1 and F2 between clusters 1, 2, and 3. Cluster 1 contained DPS highly compliant with economic, social, and environmental sustainability practices. Cluster 2 was defined by DPS with negative mean values for all three factors. Cluster 3 contained DPS that were highly compliant with F1 and F2 activities compared to cluster 2 and poorly compliant with F1 and F2 actions compared to cluster 1. Therefore, the DPS in Paraná vary according to the sustainable activities implemented by farm managers. In addition, most analyzed DPS have low survival capacity in the medium- and long-term. The most critical sustainability factor was F3, followed by F2 and F1.
\end{abstract} Key words: Competitiveness, Milk production, Environmental.

\section{Resumo}

Buscou-se analisar a tipologia de sistemas produtivos leiteiros (SPL) a partir de ações de sustentabilidade tomadas pelos produtores rurais nestes sistemas. Foram aplicados 153 formulários semiestruturados contendo variáveis de caracterização geral dos SPL, características socioeconômicas dos produtores de leite, bem como variáveis sobre as ações de sustentabilidade ambiental, social e econômica empregadas nestes sistemas. A técnica de análise fatorial comum (AFC) foi utilizada para gerar fatores de sustentabilidade. Três fatores foram gerados: econômico (F1), social (F2) e ambiental (F3). Em seguida, a partir dos scores fatoriais, foi empregada técnica de formação de clusters hierárquicos. Três clusters foram definidos e comparados frente a F1, F2 e F3. Foram identificadas diferenças para F1 e F2 entre os clusters 1,2 e 3 . O cluster 1 foi definido por SPL com os melhores resultados para as práticas de sustentabilidade econômica, social e ambiental. O cluster 2 foi definido por SPL com valores médios negativos para os três fatores. O cluster 3, foi definido por SPL com bons resultados para F1 e F2, frente aos SPL do cluster 2. Entretanto, o cluster 3 apresentou piores resultados quando comparado com o cluster 1. Foi identificada grande variabilidade nas ações de sustentabilidade empregadas nos SPL paranaenses

1 Dra em Zootecnia, Universidade Estadual de Maringá, UEM, Maringá, PR, Brasil. E-mail: kellen.kuwahara@gmail.com

2 Profs. Drs., Departamento de Zootecnia, UEM, Maringá, PR. Brasil. E-mail: jcdamasceno1@gmail.com; ferencistvan@gmail.com

3 M.e em Zootecnia, UEM, Maringá, PR. Brasil. E-mail: rodrigoprizon@gmail.com

4 Prof. Dr., Departamento de Estatística, UEM, Maringá, PR. Brasil. E-mail: diogo.rossoni@gmail.com

5 Discente, Curso de Doutorado, Programa de Pós-Graduação em Zootecnia, Universidade Estadual do Oeste do Paraná, UNIOESTE, Marechal Cândido Rondon, PR. Brasil. E-mail: eckstein@zootecnista.com.br

* Author for correspondence 
analisados. A maior parte destes sistemas apresentou baixa adequação para a sustentabilidade. $\mathrm{O}$ fator de sustentabilidade mais crítico foi o ambiental, seguido pelo social e econômico.

Palavras-chave: Competitividade. Produção de leite. Meio ambiente.

\section{Introduction}

Since the 1990s, dairy production in Brazil and Paraná has faced the challenge of maintaining their production systems in new institutional and market environments (JANK et al., 1999; BÁNKUTI et al., 2014; RODRIGUES et al., 2010) with more stringent requirements for reducing social and environmental impacts of agricultural activities (FIGUEROLA et al., 2012; FONSECA, 2012). This new demand dictates the economic, social, and ecological equilibrium in production systems, under penalty of interruption of these systems in the medium- and long-term (ELKINGTON, 2001; GDAA, 2015; FAO; IDF, 2013; SAFA, 2013).

For Brazilian dairy production systems (DPS), social and environmental compliance is urgent, especially considering the economic and social importance of these systems. In 2016, Brazil was the fourth largest producer of milk worldwide, with a volume of 33.6 billion liters (FAO, 2016). Most of the production has been generated in family businesses and has occupied areas where other crops are less viable (SILVA JUNIOR et al., 2012). Milk is produced in all Brazilian municipalities and states. The state of Paraná has one the highest milk production volumes in Brazil, accounting for approximately $12 \%$ of the Brazilian production (IBGE, 2015). In this state, 114,500 families derive their income from milk production (IPARDES, 2008). In Paraná, milk production varies according to the structural, productive, management, and social characteristics of farm managers (BRITO et al., 2015a; YABE et al., 2015; ZIMPEL et al., 2017).

The variability in production systems and management strategies imposes greater challenges for the government and the organs involved in the production chain, and generalized actions aimed at improving production and sustainability may be ineffective because of this high heterogeneity
(BRITO et al., 2015a; YABE et al., 2015; ZIMPEL et al., 2017).

Therefore, identifying analytical methods that consider these differences and allow adopting more effective strategies is necessary. Of these methods, typology studies are considered adequate (LANGE et al., 2016; DEDIEU et al., 2011; BODENMÜLLER FILHO et al., 2010; MOURA et al., 2010).

The objective of this study is to analyze the typology of DPS in Paraná based on sustainable actions implemented by farm managers.

\section{Materials and Methods}

A semi-structured questionnaire was elaborated and applied between May 2014 and February 2015 in 153 DPS located in the western, southwestern, and central-northern regions of the state of Paraná. These regions were defined by their importance in milk production (IBGE, 2015) and the heterogeneity of the DPS (BRITO et al., 2015; IPARDES, 2008).

The DPS were identified using contact lists provided by the Institute of Technical Assistance and Rural Extension (Instituto de Assistência Técnica e Extensão Rural-EMATER), dairy farms, and city halls in the evaluated regions. Sampling was random, and the questionnaires were answered individually by milk producers (SCHLECHT; SPILLER, 2012).

The questionnaires included variables related to general characteristics of DPS, socioeconomic characteristics of agricultural producers, as well as environmental, social, and economic sustainability activities implemented by producers.

The data on the general characteristics of the DPS and socioeconomic characteristics of farmers were collected from metric responses. The information on the sustainable practices adopted by farmers 
was collected from ordinal or dichotomous answers (Chart 1). A Likert-type scale (LIKERT, 1932) was used for ordinal answers with a scale ranging from zero to ten (LIMA et al., 2013; SCHLECHT; SPILLER, 2012). Closed questions with a scale ranging from zero to ten facilitated assessing the interviewees LIMA et al., 2013).

The collected data were compiled and statistically analyzed using the Statistical Package for Social Science (SPSS) version 18. First, descriptive variables, means and frequencies, and general characteristics of the DPS were analyzed. After that, common factor analysis (CFA) was used for 19 variables related to production, economic, social, and environmental practices (Table 1). CFA is a technique used to condense a large dataset into a smaller set of variables (factors) with the least possible information loss (HAIR JÚNIOR et al., 1998).

Table 1. Variables used in the analysis.

\begin{tabular}{lcc}
\hline \multicolumn{1}{c}{ Variable } & Responses & Type Description \\
\hline Milk production (liters of milk per day) & Absolute value & Metric \\
Number of dairy cows & Absolute value & Metric \\
Number of lactating cows & Absolute value & Metric \\
Milk yield (liter of milk per cow per day) & Absolute value & Metric \\
Milk production in each facility (liters per ha) & Absolute value & Metric \\
Individual records for animal control & Numerical value & Ordinal \\
Type of control of milk production & Numerical value & Ordinal \\
Financial management of dairy farming & Numerical value & Ordinal \\
Percentage of family businesses & Numerical value & Metric \\
\hline Weekly rest & $1-$ No & Dichotomous \\
Annual vacation & $2-$ Yes & \\
\hline Pasture condition & $1-$ No & Dichotomous \\
Soil condition & 2- Yes & Ordinal \\
Pasture management & Numerical value & Ordinal \\
Practices complying with the new Forest Code & Numerical value & Ordinal \\
Condition of animal facilities & Numerical value & Ordinal \\
Need for riparian forests & Numerical value & Ordinal \\
Presence of springs in the property & Numerical value & Dichotomous \\
Importance of environmental preservation for milk production & Numerical value & Ordinal \\
\hline
\end{tabular}

For CFA, 19 variables related to the sustainable practices adopted in the DPS were initially tested. However, only 16 variables remained in the analysis because the others presented a correlation lower than 0.5 (FÁVERO et al., 2009).
Principal component analysis, Varimax-type rotation, Kaiser Meyer Olkin (KMO) normalization, and the Bartlett sphericity test (SMITH et al., 2002; LEBART, 2000) were used as extraction methods in CFA. The variables with low and intermediate 
factor loads were excluded (FÁVERO et al., 2009). The number of factors was selected using the KMO criterion (FÁVERO et al., 2009; HAIR JUNIOR et al., 2009). The generated factors were classified by the variables that defined them.

Hierarchical clusters were formed using the factor scores obtained in the CFA. This method forms groups of individuals different from each other but with a similar internal profile (FÁVERO et al., 2009). Hierarchical clustering and CFA were used to evaluate the DPS according to the mean factor scores (BRITO et al., 2015b; GIE YONG; PEARCE, 2013).

The Kruskal-Wallis non-parametric test (KRUSKA; WALLIS, 1952) was used to assess the similarity between clusters, and the Wilcoxon ranksum test with cluster-wise correction was used as the post-hoc test (OGLE, 2017).

\section{Results and Discussion}

With regard to the general characteristics of the DPS, the mean property area was 47.9 hectares, with a minimum of $<1.0$ hectare and a maximum of 1,331 hectares. The mean number of dairy cows was 42.0, and the mean number of lactating cows was 22.0. The mean milk yield was 13.58 liters per cow per day, with a minimum and maximum yield of 2.0 and 30 liters per cow per day, respectively (Table 2).

Table 2. Characterization of dairy production systems.

\begin{tabular}{lccccc}
\hline Variables & $\mathrm{N}$ & Minimum & Maximum & Mean & Standard deviation \\
\hline Total area of the property (ha) & 153 & 0.60 & $1,331.00$ & 47.92 & 162.89 \\
Milk production (liters per day) & 153 & 20.00 & $2,000.00$ & 324.62 & 317.79 \\
Number of dairy cows & 153 & 5.00 & 180.00 & 42.64 & 30.12 \\
Number of lactating cows & 153 & 3.00 & 72.00 & 22.15 & 14.36 \\
Milk yield (liters of milk per cow per day) & 153 & 2.00 & 30.00 & 13.57 & 6.28 \\
Milk production in each facility (liters per ha) & 153 & 0.86 & 134.00 & 28.90 & 27.10 \\
\hline
\end{tabular}

The CFA with 16 variables resulted in a KMO value of 0.814 and Bartlett test value of 0.00 , indicating adequacy of the variables to the method (FÁVERO et al., 2009).

The first three factors explained $63.71 \%$ of the total variance among the 153 DPS, satisfying the minimum criterion of 50\% (BARROSO; ARTES, 2003). The highest variance was explained by factor $1(39.73 \%)$, indicating that this factor better differentiated the 153 DPS, followed by factor 2 $(14.28 \%)$ and factor $3(9.69 \%)$ (Table 3$)$.

Table 3. Total variance explained.

\begin{tabular}{cccc}
\hline Factors & Total & \% change & cumulative $\%$ \\
\hline F1 & 6.357 & 39.733 & 39.733 \\
F2 & 2.285 & 14.280 & 54.012 \\
F3 & 1.552 & 9.698 & 63.711 \\
F4 & 1.097 & 6.854 & 70.564 \\
\hline
\end{tabular}


Factor 1 (F1) was defined by milk production (liters per day), number of dairy cows, number of lactating cows, milk yield (liters of milk per cow per day), milk production per area (liters per ha), individual records for control of animals, type of control of milk production, and use of financial management of milk production (Table 4). F1 was denominated economic because it was formed primarily by production and economic variables.

Table 4. Factor load for factor definition.

\begin{tabular}{lccc}
\hline Variables & F1 & F2 & F3 \\
\hline Milk production (liters of milk per day) & $\mathbf{0 . 8 1}$ & 0.47 & 0.04 \\
Number of dairy cows & $\mathbf{0 . 6 5}$ & 0.58 & -0.18 \\
Number of lactating cows & $\mathbf{0 . 6 5}$ & 0.57 & -0.03 \\
Milk yield (liters of milk per cow per day) & $\mathbf{0 . 7 8}$ & 0.04 & 0.24 \\
Milk production (liters per ha) & $\mathbf{0 . 7 5}$ & -0.20 & 0.17 \\
Individual records for animal control & $\mathbf{0 . 6 3}$ & 0.17 & 0.36 \\
Type of control of milk production & $\mathbf{0 . 6 3}$ & 0.19 & 0.44 \\
Financial management of dairy farming & $\mathbf{0 . 5 4}$ & 0.05 & 0.44 \\
Weekly rest & 0.19 & $\mathbf{0 . 7 5}$ & 0.22 \\
Annual vacation & 0.02 & $\mathbf{0 . 8 9}$ & 0.14 \\
Percentage of family businesses & -0.03 & $\mathbf{- 0 . 8 9}$ & -0.13 \\
Pasture condition & 0.47 & 0.04 & $\mathbf{0 . 5 7}$ \\
Soil condition & 0.38 & 0.17 & $\mathbf{0 . 5 2}$ \\
Pasture management & 0.26 & 0.19 & $\mathbf{0 . 7 3}$ \\
Practices complying with the new Forest Code & 0.04 & -0.05 & $\mathbf{0 . 6 3}$ \\
Condition of animal facilities & -0.02 & 0.40 & $\mathbf{0 . 6 0}$ \\
\hline
\end{tabular}

F1: economic factor; F2: social factor; F3: environmental factor.

Economic adequacy, one of the pillars of sustainability, is related to the capacity of families of agricultural producers to remain in the dairy business in the medium- and long-term. This variable is essential for determining the characteristics of the DPS of Paraná, which are formed primarily by family businesses and a strong dependence on milk income (IPARDES, 2008).

Milk production and milk yield in F1 represent conditions necessary for farmers to maintain the DPS in formal markets and lower risk in the medium- and long-term. Therefore, specialized systems produce a sufficient volume of milk that makes unit costs (per unit area or animal) lower than the costs of lower-volume systems (SIMÕES et al., 2009).
Production volume is directly associated with the total number of dairy cows and the number of lactating cows. Moreover, higher production volumes generate higher prices for the rural producer and greater bargaining power in the transactions with the beneficiation industry.

Factor 2 (F2) was defined by the percentage of family businesses, weekly rest, and annual vacation. F2 was designated social factor because of the characteristics of these variables (Table 4).

The Labor Legislation states that workers should have a formal employment contract, a weekly rest period of 24 continuous hours, annual vacation, and Christmas bonus. Salary [Consolidated Labor Laws (Consolidação das Leis do Trabalho-CLT), Decree- 
Law No. 5,452, of May 1, 1943]. Failure to comply with these legal issues may result in informal work and carry penalties to rural workers. In addition, social responsibility creates direct benefits to the business sustainability in the medium- and longterm because of the legal and market requirements (MARTINS et al., 2015).

Social compliance may result in higher yields for DPS because of the higher motivation of workers and better conditions and quality of life in the work environment (MARTINS et al., 2015).

Factor 3 (F3) was defined by pasture condition, soil condition, pasture management, practices complying with the new Forest Code, and conditions of animal facilities. Therefore, F3 was named environmental factor (Table 4).

F2 and F3 represent a legal condition for the existence and permanence of milk activity in consumer markets. The lack of compliance with the new Forest Code may cause greater difficulty in access to credit and preclude the register of the dairy production system in the Rural Environmental Registry (Cadastro Ambiental Rural-CAR), thus limiting the growth of these systems.

Cluster analysis defined the typology of the three factors (Table 5) and three groups of DPS considering the factor scores (Table 6).

Table 5. Characterization of each cluster.

\begin{tabular}{lcccc}
\hline \multicolumn{1}{c}{ Cluster } & & 1 & 2 & 3 \\
\hline \multirow{3}{*}{ Milk production (liters of milk per day) } & Minimum & 500.0 & 20.0 & 48.0 \\
& Maximum & 2000.0 & 1000.0 & 800.0 \\
& Mean & 970.71 & 251.09 & 309.9 \\
Number of dairy cows & Minimum & 43.0 & 5.0 & 23.0 \\
& Maximum & 180.0 & 150.0 & 88.0 \\
& Mean & 96.43 & 35.56 & 47.15 \\
Number of lactating cows & Minimum & 25.0 & 3.0 & 11.0 \\
& Maximum & 72.0 & 52.0 & 65.0 \\
& Mean & 47 & 18.46 & 26.75 \\
Milk yield (liters of milk per cow per day) & Minimum & 11.0 & 2.0 & 4.0 \\
& Maximum & 30.0 & 29.0 & 22.0 \\
& Mean & 20.57 & 13.06 & 11.8 \\
Milk production (liters per ha) & Minimum & 16.0 & 1.0 & 0.9 \\
& Maximum & 82.6 & 134.0 & 46.5 \\
& Mean & 42.77 & 29.47 & 15.82 \\
\hline
\end{tabular}

Table 6. Mean values of the factor scores of each cluster.

\begin{tabular}{cccccc}
\hline Cluster & $\mathrm{N}$ & $\%$ & Economic factors (F1) & Social factors (F2) & Environmental factors (F3) \\
\hline 1 & 16 & 10.46 & $1.03^{\mathrm{a}}$ & $1.95^{\mathrm{a}}$ & $-0.31^{\mathrm{b}}$ \\
2 & 118 & 77.12 & $-0.02^{\mathrm{c}}$ & $-0.49^{\mathrm{c}}$ & $-0.10^{\mathrm{b}}$ \\
3 & 19 & 12.42 & $-0.73^{\mathrm{b}}$ & $1.41^{\mathrm{b}}$ & $0.91^{\mathrm{a}}$ \\
Total & 153 & 100 & - & - & - \\
\hline
\end{tabular}

Different letters in each column indicate differences using the Wilcoxon rank sum test with cluster-wise correction at a level of significance of $5 \%$. 
Sixteen DPS (10.46\%) were allocated to cluster 1, $118(77.12 \%)$ to cluster 2 , and $9(12.42 \%)$ to cluster 3. The groups of DPS were compared using the mean factor scores (Table 6). Cluster 1 was located entirely in the upper right quadrant and contained DPS with scores indicating good compliance with F1 and F2 (Figure 1).

Figure 1. Dispersion of the DPS for factors 1 and 2.

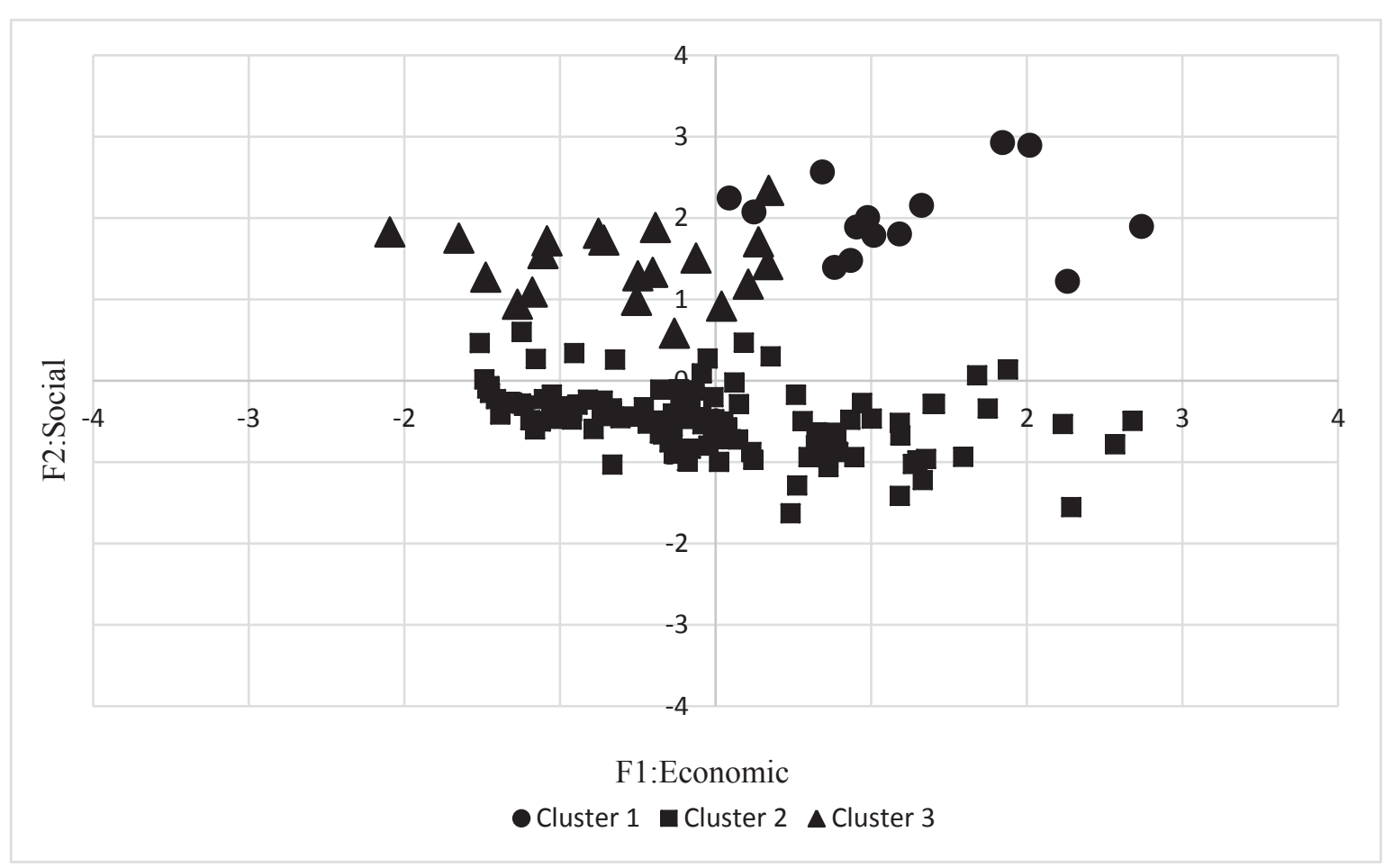

Cluster 2 was located in the lower quadrants. The DPS with scores indicating poor compliance with F1 and F2 were located in the lower left quadrant whereas the DPS with good adherence to F1 were located in the lower right quadrant (Figure 1).

Cluster 3 was concentrated in the upper quadrants, predominantly in the left quadrant, and contained
DPS with scores indicating good compliance with F2, but poor compliance with F1 (Figure 1).

Cluster 1 was mostly concentrated in the lower right quadrant and contained DPS highly compliant with F1 practices but poorly compliant with F3 practices (Figure 2). 
Figure 2. Dispersion of the DPS for factors 1 and 3.

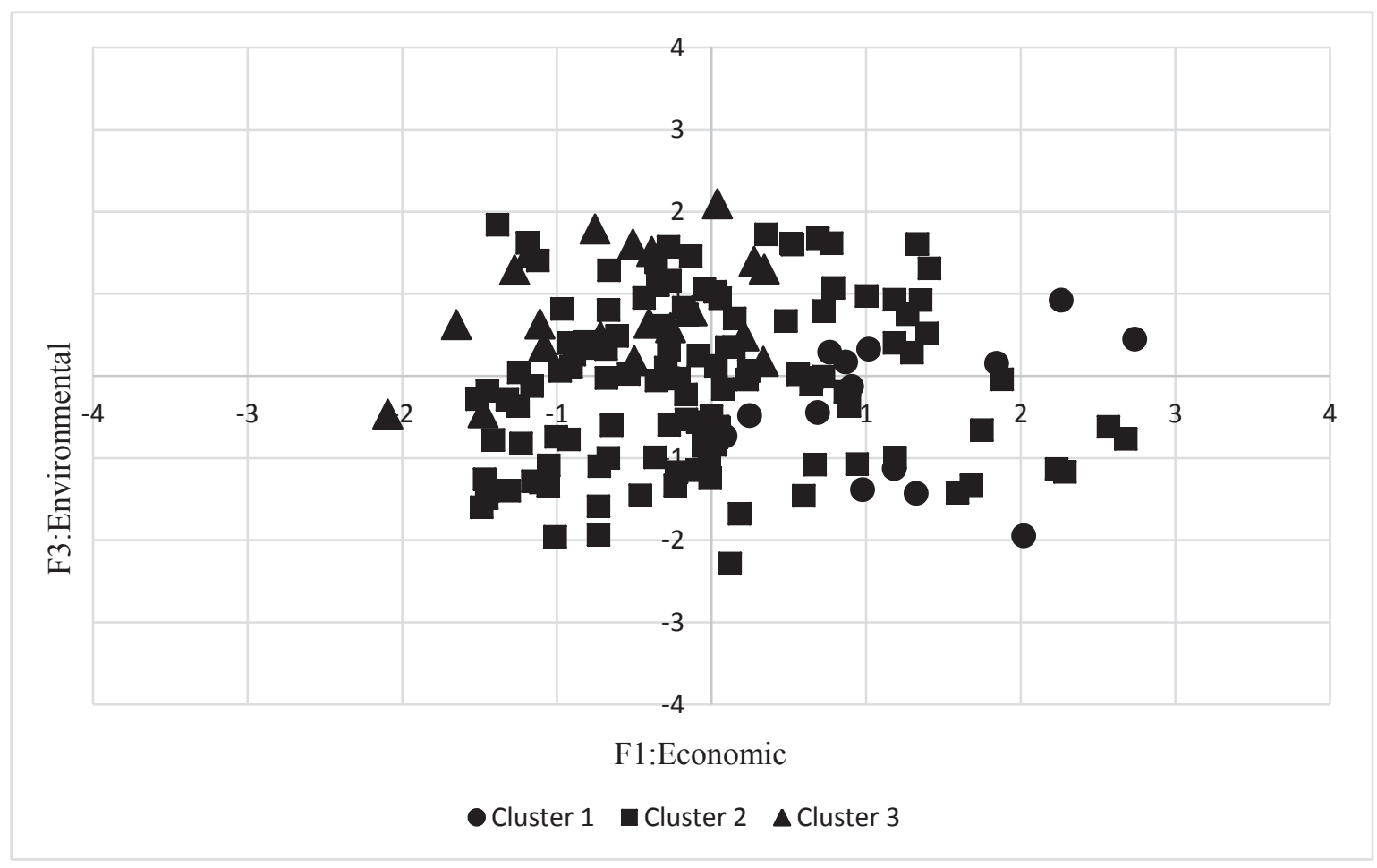

In contrast, cluster 2 was located in the lower quadrants. The DPS with scores indicating good adherence to F1 and F3 were located in the lower left quadrant whereas those with good adherence to F1 but poor compliance with F3 were located in the lower right quadrant (Figure 2).

Cluster 3 was predominantly located in the upper left quadrant and contained DPS highly compliant with F1 and F3 (Figure 2).

Therefore, cluster 1 contained DPS with good compliance with F1 and F2 actions compared to the other clusters $(\mathrm{p}<0.05)$ (Table 5 and Figures 1 and 2). This result indicates that cluster 1 is formed by DPS with larger production scale and volume, and more dairy and lactating cows. Furthermore, the DPS in cluster 1 presented higher milk yield per animal and area (Table 5).

Cluster 1 also contained DPS with better control of milk production and better management of financial activity compared to the DPS in clusters 2 and 3 (Table 6).

The DPS in cluster 1 had a higher percentage of hired workers and farmers who complied with rules related to weekly rest and annual vacation for the workers compared with the DPS in clusters 2 and 3 (Table 5). Therefore, the DPS in cluster 1 had more social concerns about the impact of the production system on human and animal welfare, the adaptation of animals to the animal facilities, and the work environment, and this result corroborates with those of Sydorovych and Wossink (2008), and Van Calker et al. (2005).

These results indicate that the DPS in cluster 1 are better adapted to market demands, milk volume and quality, and therefore tend to obtain a better value per liter of commercialized milk and higher profitability with milk production (IPARDES, 2008).

The fact that the DPS in cluster 1 had higher compliance with F1 actions than the other DPS 
may be related to the profile of producers working in the dairy industry and classified as "modern conventional to modern industrial" (OKANO, 2012).

The production systems in cluster 1 presented lower compliance with F3 than the DPS in cluster $3(p<0.05)$ but were not significantly different from the DPS in cluster 2 ( $>00.05)$. Therefore, compared to cluster 3 , cluster 1 is formed by DPS that adopt fewer environmental sustainability practices, including improvements in pasture and soil conditions, routine pasture management practices, better compliance with the new Forest Code, and conditions that improve animal welfare (Table 6 and Figures 1 and 2).

Although the DPS in cluster 1 achieved the best results for F1, F2, and F3 if compared to the DPS in the other clusters, practices that improve the sustainability of F3 - the most critical factorshould be prioritized, and the sustainability of F1 and F2 should be improved in all cases.

It is of note that cluster 1 contained a smaller number of DPS (16); therefore, this cluster represents a small percentage of the analyzed cases (Table 6).

The DPS in cluster 1 adopted more consistent actions for economic, social, and environmental sustainability (Table 6 and Figures 1 and 2) and consequently had better survival capacity in the medium- and long-term compared to the production systems in clusters 2 and 3.

The DPS in cluster 2 presented negative mean values for all three factors and lower compliance with F2 $(\mathrm{p}<0.05)$ compared to the DPS in the other clusters (Table 6).

The production systems in cluster 2 presented lower adherence to F3 than the DPS in cluster 3 $(p<0.05)$ but were not significantly different from the DPS in cluster $1(\mathrm{p}>0.05)$ (Table 5 and Figures 1 and 2). These results indicate that the majority $(77.12 \%)$ of the analyzed DPS presented important obstacles to economic, social, and environmental sustainability practices (Table 6).

Compared to the other clusters, the DPS in cluster 2 adopted fewer economic, social, and environmental sustainability practices (Table 6 and Figures 1 and 2). Therefore, cluster 2 is formed by DPS with a low likelihood of survival in the medium- and long-term (FARINA et al., 1997).

For the DPS in cluster 2, economic and social compliance should be prioritized, and environmental sustainability actions should be improved to increase the likelihood of survival.

Cluster 3 contained DPS with good adherence to F2 compared to the DPS in cluster $2(p<0.05)$ and poor adherence to F2 compared to the DPS in cluster $1(\mathrm{p}<0.05)$. The DPS in cluster 3 presented poor compliance with F1 compared to the systems in clusters 1 and 2 (Table 6).

The DPS in cluster 3 presented good compliance with F3 compared with the systems in the other clusters $(p<0.05)$ (Table 6 and Figures 1 and 2). Therefore, the DPS in cluster 3 adopt sustainable environmental practices in most cases. The strongest limitation to sustainability in cluster 3 in the medium- and long-term compared to cluster 1 is economic and social adequacy. Therefore, the DPS in cluster 3 have moderate survival capacity in this time frame.

Considering these results, practices that improve economic, social, and environmental sustainability should be implemented by the DPS in Paraná. These practices include soil conservation by grazing and analysis of the impact of anthropic actions related to pasture management. Another strategy that improves sustainability is the dissemination of information on the importance of sustainability practices for the survival of dairy production systems in the mediumand long-term.

F1 can be improved by performing actions related to the increase in dairy production and training in the management of the DPS. 
The training of workers involved in dairy production is vital for developing these systems, with benefits for the entire milk production chain (REIS FILHO; SILVA, 2013). Regarding this, the role of public technical assistance institutions is fundamental. In addition, private actions, especially those from industry, related to price formation and direct contact with new markets, may improve the sustainability of these systems in the medium- and long-term.

\section{Conclusion}

The degree of compliance of the DPS of Paraná with social and environmental practices, considering the measures adopted by farm managers, is variable.

Environmental sustainability factors, followed by social and economic factors, were the most critical for the sustainability of the analyzed DPS. Therefore, these production systems need to implement significant changes to increase their survival in the medium- and long-term.

\section{Acknowledgments}

The authors are grateful to the Araucária Foundation and the Secretariat of Science, Technology, and Higher Education of Paraná for funding the research project titled "Valuation of dairy production systems with a low negative impact: a proposal for social and environmental certification" (Agreement No. 265/2014); the dairy producers of Paraná and dairy companies that contributed to the research; and the funding and technical assistance agencies of Paraná.

\section{References}

BÁNKUTI, F. I.; BÁNKUTI, S. M. S.; CASTRO, P. L. de; BRITO, M. M.; FARIAS, C. V. T.; DAMASCENO, J. C. Análise da Competitividade potencial da produção leiteira na microrregião de Maringá. Informações Econômicas, São Paulo,v. 44, n. 1, p. 42 - 54, 2014.
BARROSO, L.P.; ARTES, R. Análise multivariada. Lavras: UFLA, $2003.152 \mathrm{p}$.

BODENMÜLLER FILHO, A.; DAMASCENO, J. C.; PREVIDELLI, I. T. S.; SANTANA, R. G.; RAMOS, C. E. C.; SANTOS, G. T. Tipologia de sistemas de produção baseada nas características do leite Typology of production systems based on the milk characteristics. Revista Brasileira de Zootecnia, Viçosa, MG, v. 39, n. 8, p. 1832-1839, 2010.

BRITO, M. M.; BÁNKUTI, F. I.; BÁNKUTI, S. M. S.; FERREIRA, M. C. M.; DAMASCENO, J. C.; SANTOS, G. T.; ZAMBOM, M. A. Horizontal arrangements: strategy for reducing the asymmetry information for dairy farmers in Paraná, Brazil. Ciência Rural, Santa Maria, v. 45, n. 11, p. 2069-2075, nov. 2015.

BRITO, M. M.; BÁNKUTI, F. I.; BÁNKUTI, S. M, C.; SANTOS, G. T.; DAMASCENO, J. C.; MASSUDA, E. M. Horizontal arrangements and competitiveness of smallscale dairy farmers in Paraná, Brazil. International Food and Agribusiness Management Review, Minneapolis, v. 18 , n. 4, p. 155-172, 2015.

DEDIEU, B.; AUBIN, J.; DUTEURTRE, G.; ALEXANDRE, G.; VAYSSIERES, J.; BOMMEL, P.; FAYE, B.; MAHIEU, M.; FANCHONE, A.; TOURRAND, J. F.; ICKOWICZ, A. Design and evaluation of sustainable livestock farming systems in warm regions. Inra Productions Animales, Paris, v. 24, n. 1, p. 113-128, 2011.

ELKINGTON, J. Enter the triple bottom line. Routledge, v. 1, n. 1986, p. 1-16, 2001.

FARINA, E. M. Q.; AZEVEDO, P. F.; SAES, M. S. Comptitividade: mercado, estado e organizações. São Paulo: Ed. Singular, 1997. 286 p.

FOOD AND AGRICULTURE ORGANIZATION OF THE UNITED NATIONS - FAO/IDF. Guia de boas práticas na pecuária de leite. Produção e Saúde Animal Diretrizes. Rome: FAO. 2013. Disponível em: www.fao. org/DOCREP/006/Y5224E/Y5224E00.htm eftp://ftp. fao.org/docrep/fao/006/y5224e/y5224e00.pdf. Acesso em: 20 nov. 2016.

FÁVERO, L. P.; BELFIORE, P. P.; SILVA, F. L. da; CHAN, B. L. Análise de dados: modelagem multivariada para tomada de decisões. Rio de Janeiro: Elsevier, 2009b. $544 \mathrm{p}$.

FIGUEROLA, E. L. M.; GUERRERO, L. D.; ROSA, S. M.; SIMONETTI, L.; DUVAL, M. E.; GALANTINI, J. A.; BEDANO, J. C.; WALL, L. G.; ERIJMAN, LO. Bacterial indicator of agricultural management for soil under no-till crop production. PLoS ONE, San Francisco, California, v. 7, n. 11, p. 1677-1687 2012. 
FONSECA, L. R. Agropecuária e certificação ambiental: oportunidades e desafios no Distrito Federal. 2012. Dissertação (Mestrado em Planejamento e Gestão Ambiental) - Universidade Católica de Brasília, Brasília, DF.

GLOBAL DAIRY AGENDA FOR ACTION - GDAA. El sector lácteo: listo para ayudar a alcanzar los objetivos de desarrollo sustentable. Global Dairy Agenda for Action. Belgium: GDAA, 2015. Disponível em: $<$ http://dairysustainabilityframework.org/wp-content/ uploads/2015/11/El-sector-1\%C3\%A 1 cteo-listopara-ayudar-a-alcanzar-los-objetivos-de-desarrollosustentable.pdf $>$. Acesso em: 15 abr. 2017.

GIE YONG, A.; PEARCE, S. A Beginner's guide to factor analysis: focusing on exploratory factor analysis. Tutorials in Quantitative Methods for Psychology, v. 9, n. 2, p. 79-94, 2013.

HAIR JUNIOR, J.; ANDERSON, R. E.;TATHAN, R. L.; BLACK, W. C. Multivariate data analysis. New Jersey: Prentice Hall, 1998. 768 p.

HAIR, J.; BLACK, W. C.; BABIN, B. J.; ANDERSON, R. E. Multivariate data analysis. Saddle River: Prentice Hall, 2009. 816 p.

INSTITUTO BRASILEIRO DE GEOGRAFIA E ESTATÍSTICA - IBGE. Indicadores IBGE - Estatística da produção pecuária. Brasília: IBGE, 2015. Disponível em: $<$ http://www.ibge.gov.br/home/estatistica/ indicadores/ agropecuaria/producaoagropecuaria/abate-leite-couroovos_201501_publ_completa.pdf $>$. Acesso em: 19 jan. 2016.

INSTITUTO

PARANAENSE

DE DESENVOLVIMENTO ECONÔMICO E SOCIAL IPARDES. Caracterização socioeconômica da atividade leiteira no Paraná. [s.l: s.n.], 2008. Disponível em: $<$ http://www.ipardes.gov.br/biblioteca/docs/sumario executivo_atividade_leiteira_parana.pdf $>$. Acesso em: 10 dez. 2015.

JANK, M. S.; GALAN, V. B. Competitividade do sistema agroindustrial do leite. IPEA/PENSA/USP, p. 39-61, 1998.

KRUSKAL, W. H.; WALLIS, W. A. Source: journal of the american statistical association. American Statistical Association, Lomdon, v. 47, n. 260, p. 583-621, 1952.

LANGE, M. J.; ZAMBOM, M. A.; RAMOS, C. E. C. O. de; CASTAGNARA, D. D.; FERENC, I.; NEUMANN, M. E.; BRITO, M. M. de; TININI, R. O. C. R. de. Tipologia de sistemas de produção leiteiros baseado nas características produtivas e de manejo na Região Oeste do Paraná. Semina: Ciências Agrárias, Londrina, v. 37, n. 1, p. 473-481, 2016.
LEBART, L. Contiguity analysis and classification. In: GAUL, W.; OPITZ, O.; SCHADER, M. (Ed.). Data analysis. Berlin: Springer, 2000. p. 233-243.

LIKERT, R. A technique for the measurement of attitudes Archives of Psychology, Washington, v. 22, n. 3, p. 22-44, 1932. Disponível em: <http://psycnet.apa.org/ psycinfo/1933-01885-001>. Acesso em 22 nov. 2016.

LIMA, I. F. de; OLIVEIRA, H. P. C. de; SANTANA, S. R. de. Metodologia para avaliação do nível de usabilidade de bibliotecas digitais: um estudo na Biblioteca Virtual de Saúde. Transinformação, Campinas, v. 25, n. 2, p. 135-143, 2013.

MARTINS, P. do C.; PICCININI, G. A.; KRUG, E. E. B.; MARTINS, C. E.; LOPEZ, F. C. F. Sustentabilidade ambiental, social e econômica da cadeia produtiva do leite: desafios e perspectivas. Brasília: Embrapa Gado de Leite, 2015. $432 \mathrm{p}$.

MOURA, J. F. P. de.; PIMENTA FILHO, E. C.; GONZAGA NETO, S.; LEITE, S. V. de F.; GUILHERMINO, M. M.; MENEZES, M. P. C. de. Análise económica da exploração de leite no Cariri Paraibano. Acta Scientiarum - Animal Sciences, Maringá, v. 32, n. 2, p. 225-231, 2010.

OGLE, D. H. FSA: fisheries stock analysis. R package version 0.8.12. 2017.

OKANO, M. T. Construção de indicadores e métodos para a classificação de produtores de leite para melhoria do desempenho dos sistemas de produção. Gestão da Produção, Operações e Sistema - GEPROS, Bauru, v. 8, n. 4, p. 45-59, 2012.

REIS FILHO, R. J. C.; SILVA, R. G. Cenários para o leite e derivados na Região Nordeste em 2020. Recife: Sebrae, 2013. 154 p.

RODRIGUES, G. S.; BUSCHINELLI, C. C. A.; AVILA, A. F. D. An environmental impact assessment system for agricultural research and development II: institutional learning experience at embrapa. Journal of Technology Management and Innovation, Santiago, Chile, v. 5, n. 4, p. 38-56, 2010.

SUSTAINABILITY ASSESSMENT OF FOOD AND AGRICULTURE SYSTEMS - SAFA. Indicators. Rome: FAO, 2013. $271 \mathrm{p}$.

SCHLECHT, S.; SPILLER, A. A Latent class cluster analysis of farmers' attitudes towards contract design in the dairy industry. Agribusiness, West Sussex, v. 28, n. 2, p. 121-134, 2012.

SILVA JUNIOR, J. F. L.; OLIVEIRA R. C. E. C. de; SANTOS, G. T.; GRANDE, P. A.; DAMASCENO, J. C.; MASSUDA, E. M. Análise das práticas de produtores 
em sistemas de produção leiteiros e seus resultados na produção e qualidade do leite. Semina: Ciências Agrarias, Londrina, v. 33, n. 3, p. 1199-1208, 2012.

SIMÕES, A. R. P.; SILVA, R. M.; OLIVEIRA, M. V. M.; CRISTAlDO, R. O.; BRITO, M. C. B. Avaliação econômica de três diferentes sistemas de produção de leite na região do Alto Pantanal Sul-Mato-Grossense. Revista Agrarian, Dourados, v. 2, n. 5, p. 153-167, 2009.

SMITH, R. R.; MOREIRA, V. L.; LATRILLE, L. L. Caracterización de sistemas productivos lecheros en la $\mathrm{x}$ región de Chile mediante análisis multivariable. Agricultura Técnica, Chillán, v. 62, n. 3, p. 375-395, 2002.

SYDOROVYCH, O.; WOSSINK, A. The meaning of agricultural sustainability: evidence from a conjoint choice survey. Agricultural Systems, Amsterdam, v. 98, n. 1, p. 10-20, 2008.
VAN CALKER, K. J.; BERENTSEN, P. B. M.; GIESEN, G. W. J.; HUIRNE, R. B. M. Identifying and ranking attributes that determine sustainability in Dutch dairy farming. Agriculture and Human Values, Amsterdam, v. 22, n. 1, p. 53-63, 2005.

YABE, M. T.; BÁNKUTI, F. I.; DAMASCENOS, J. C.; BRITO, M. M. Characteristics of milk production systems and feed strategies for dairy cows in the North and Northwest of Paraná State. Semina: Ciências Agrárias, Londrina, v. 36, n. 6, p. 4469-4480, 2015.

ZIMPEL, R.; BÁNKUTI, F. I.; ZAMBOM, M. A.; KUWAHARA, K. C.; BÁNKUTI, S. M. S.What are the characteristics of the dairy farmers who perform financial management in Paraná state. Revista Brasileira de Zootecnia, Viçosa, v. 46, n. 5, p. 421-428, 2017. 